\title{
Defects in the first wave of folliculogenesis in mouse XO ovaries
}

\author{
Kento MIURA ${ }^{1)}$, Chiharu MURATA ${ }^{1}$, Kyoko HARIKAE ${ }^{1}$, Hitomi SUZUKI ${ }^{2)}$, \\ Masami KANAI-AZUMA' ${ }^{2)}$, Masamichi KUROHMARU1), Naoki TSUNEKAWA ${ }^{1)}$ and \\ Yoshiakira KANAI ${ }^{1}$ \\ 1) Department of Veterinary Anatomy, The University of Tokyo, Tokyo 113-8657, Japan \\ ${ }^{2)}$ Department of Experimental Animal Model for Human Disease, Center for Experimental Animals, Tokyo Medical and \\ Dental University, Tokyo 113-8510, Japan
}

\begin{abstract}
In mouse ovaries, the first wave of folliculogenesis perinatally starts near the medullary region, which directs the initial round of follicular growth soon after birth. At the same time, cortical primordial follicles start forming in the ovarian surface region, and then some are cyclically recruited for the second and subsequent rounds of follicular growth. Recent studies suggest different dynamics between the first and subsequent waves of follicular growth in postnatal ovaries. However, the phenotypic differences between these phases remain unclear. Here, we show direct evidence that XO female mice, a murine model for Turner Syndrome, lack the first wave of folliculogenesis. Our histopathological analyses of XX and XO littermates revealed a lack of anti-Müllerian hormone (AMH)-positive primary follicles in the XO ovaries by 4 days post partum (dpp). This loss of first follicles was also confirmed by histological bioassay for SRY-dependent SOX9 inducibility, a specific marker for the first follicular granulosa cells. In contrast, cortical primordial follicles formed properly in XO ovaries, and some of them formed primary and secondary follicles in the subcortical region by $7 \mathrm{dpp}$. They rapidly developed into late antral follicles, showing similarities to XX littermate ovaries by $21 \mathrm{dpp}$. These results suggest distinct X-monosomy effects between the first and subsequent waves of follicular growth, highlighting the high susceptibility to elimination of XO oocytes in the first wave of mammalian folliculogenesis.
\end{abstract}

Key words: Anti-Müllerian hormone (AMH), Folliculogenesis, Granulosa cell, Oocyte, XO mice

(J. Reprod. Dev. 63: 333-338, 2017)

I n mammals, the ovarian follicle consists of the oocyte and granulosa cells, which are surrounded by interstitial steroidogenic cells such as theca cells and ovarian interstitial gland cells [1,2]. Forkhead box L2 (FOXL2) is known to play a central role in the differentiation and maintenance of granulosa cells in developing ovaries [3-6]. In XX gonads, FOXL2 is activated primarily in pre-granulosa cells at 12.0 days post coitum (dpc) in a female-specific manner, approximately one day later than the onset of two major testis factors, sex-determining region of chromosome Y (SRY) and SRY-box 9 (SOX9), in XY gonads (11.0-11.25 dpc) [1, 7]. In a heat-inducible SRY transgenic line, pre-granulosa cells are shown to maintain SRY-dependent SOX9 inducibility (SDSI) by $11.5 \mathrm{dpc}[8,9]$, but most of them undergo a rapid loss of SDSI between 11.5-12.0 dpc, suggesting that the loss of SDSI is the earliest sign of pre-granulosa cell differentiation in XX gonads [9]. Most importantly, a certain population of FOXL2-positive pre-granulosa cells near the ovarian medullary region continuously maintain SDSI throughout the fetal stages, and then contribute to the initial round of folliculogenesis soon after birth. Such loss or maintenance of SDSI in pre-granulosa

Received: March 10, 2017

Accepted: March 30, 2017

Published online in J-STAGE: April 10, 2017

C2017 by the Society for Reproduction and Development

Correspondence: Y Kanai (e-mail: aykanai@mail.ecc.u-tokyo.ac.jp)

This is an open-access article distributed under the terms of the Creative Commons Attribution Non-Commercial No Derivatives (by-nc-nd) License. (CC-BY-NC-ND 4.0: https://creativecommons.org/licenses/by-nc-nd/4.0/) cells appears to be regulated in a manner independent from other ovarian factors, including FOXL2, wingless-type MMTV integration site family, member 4 (WNT4), or retinoic acids [9], suggesting the heterogeneity of pre-granulosa cells in developing mouse ovaries.

In mammalian folliculogenesis, ovarian follicles can be categorized into two different granulosa cell populations: i) the first wave of folliculogenesis, which occurs in the medullary region soon after birth $[10,11]$, and ii) the subsequent waves of folliculogenesis near the surface cortical region, which contribute to the primordial follicle pool in the ovarian cortex $[10,12,13]$. In the first follicles, the pre-granulosa cells contribute to the first wave of follicular growth near the ovarian medullary region [10]. In contrast, the granulosa cells of the resting primordial follicles in the surface cortical region are newly recruited from the ovarian epithelia soon after birth.

A recent in vivo tracing experiment using a Foxl2-CreER ${ }^{T 2}$ line revealed that the minimum developmental time from primordial to antral follicles is faster in the first follicles than in the subsequent waves of cortical follicles at later stages $[11,14]$. As described above, the first follicles contain SDSI-positive granulosa cells [9], indicating the presence of sexually bipotential granulosa cells in the first folliculogenesis. This is consistent with the sex reversal phenotypes in the first folliculogenesis located in the centromedullary region of female pups with Foxl2-null or estrogen receptor (Esr) 1/2-double null mutations [15-19]. Because the first follicles grow before individual sexual maturation, most of them undergo atresia prior to ovulation $[11,12]$. In contrast, fertility drug treatment and in vitro fertilization make it possible to produce the next generation from 
first wave follicles [20]. At present, the biological significance of the first wave of folliculogenesis remains unknown, partly because there are few models in which first wave follicles can be studied [11, 21].

XO mice (a murine model for Turner Syndrome) have only a single X chromosome and no second sex chromosome [22]. Gonadal dysgenesis is seen in the vast majority of human Turner Syndrome cases, and almost all affected individuals are infertile [23]. Unlike their human counterparts, XO mice are typically fertile, albeit with shortened reproductive life spans [24]. These differences are partially due to fewer genes' escaping $\mathrm{X}$ chromosome inactivation and the expression of both $\mathrm{X}$ chromosome alleles in mice as opposed to humans [25]. Previous histological analyses showed that XO mice have normal ovarian development during fetal stages (14.5-18.5 $\mathrm{dpc}$ ), but only approximately half as many oocytes as XX mice postnatally due to excess atresia of oocytes around birth [26, 27]. In contrast to the extensive qualitative and quantitative analyses that have been conducted on the aberrant development of XO oocytes throughout the fetal to adult stages [26-30], little is known about the defects and susceptibilities at the somatic levels of the first and subsequent waves of folliculogenesis in XO ovaries.

In the present study, we conducted comparative histopathological analyses on postnatal ovaries in XX and XO female littermates. We also examined SDSI activity in the first follicles of the XO and XX females using a heat-inducible Sry transgenic line. We observed a complete lack of oocytes in the SDSI-positive first follicles in developing XO ovaries. The cortical follicle pool, in contrast, formed properly, and their subsequent waves of follicular growth lead to the recovery of the defective first folliculogenesis in XO ovaries by $21 \mathrm{dpp}$.

\section{Materials and Methods}

\section{Animals}

All animal experiments in this study were carried out in strict accordance with the Guidelines for Animal Use and Experimentation as set out by the University of Tokyo. The procedures were approved by the Institutional Animal Care and Use Committee of the Graduate School of Agricultural and Life Sciences of the University of Tokyo (approval ID: P13-764).

The XO mouse strain and the heat-inducible Sry transgenic line \#44 (with the HSP-Sry [Hsp 70.3 promoter-driven murine $S r y]$ transgene) [8] were used in this study (ICR/C57BL6-mixed background). The XO mouse strain (RBRC00872) was provided by the RIKEN BioResource Center through the National BioResource Project of the Ministry of Education, Culture, Sports, Science and Technology (MEXT) of Japan. Karyotyping of the XO line was conducted based on a previous report [31]. In the Sry-inducible transgenic (Hsp-Sry Tg) system, it is possible to induce XX testis sex reversal [8]. In this Hsp-Sry Tg system (referred to as "Tg” hereafter), heat shock (HS) treatment induces ectopic SRY expression (as described below), leading to transient SOX9 induction in XX Tg-supporting cells. The newborn stage, 0 day post partum (dpp), corresponds to $19.5 \mathrm{dpc}$. The phenotypes of XO and XX littermates were compared at each stage.

\section{Organ culture and heat shock (HS) treatment}

For in vitro HS treatment, neonatal ovaries were isolated from 2 dpp pups in cold Dulbecco's Modified Eagle's Medium (DMEM; Sigma). Ovaries were subjected to $\mathrm{HS}$ treatment $\left(43^{\circ} \mathrm{C}\right.$ for $\left.10 \mathrm{~min}\right)$ in a $0.2-\mathrm{ml}$ thin-walled PCR tube, as described previously [9]. After HS treatment, all samples were cultured on Nuclepore Track-Etched Membranes (Whatman) in DMEM containing 10\% fetal bovine serum at $37^{\circ} \mathrm{C}$ for $9 \mathrm{~h}$ before fixation in $4 \%$ paraformaldehyde (PFA) in phosphate buffered saline (PBS).

\section{Histology and immunohistochemistry}

The samples were fixed in $4 \%$ PFA-PBS at $4^{\circ} \mathrm{C}$ for $12 \mathrm{~h}$, dehydrated, and embedded in paraffin. Serial sections (approximately $4 \mu \mathrm{m}$ in thickness) were used for immunostaining for markers, as described previously $[21,32]$. The sections were incubated with anti-AMH (1:800 dilution; sc-6886; Santa Cruz), anti-FOXL2 (1:600 dilution; ab5096; Abcam), anti-mouse Vasa homologue (MVH; formally DEAD box polypeptide 4 [Ddx4]; 1:2,000 dilution; ab13840; Abcam), anti-SOX9 (1:10,000 dilution; AB5535; Merck Millipore), or anti-3 $\beta$ hydroxy-delta-5-steroid dehydrogenase (3 $\beta$-HSD; 1:200; sc-30821; Santa Cruz) antibody at $4^{\circ} \mathrm{C}$ for $12 \mathrm{~h}$. The reaction was visualized with a biotin-conjugated secondary antibody in combination with the Elite ABC kit (Vector Laboratories) or by Alexa-Fluor-488/594conjugated secondary antibodies (Invitrogen).

For morphometric analyses, anti-AMH-stained sectioning samples with maximum ovarian area were photographed, and the numbers of AMH-positive follicles were estimated in each image. The ovarian area was also measured histologically using Image J $1.48 \mathrm{~V}$ software (National Institutes of Health, Bethesda, MD, USA), and the relative numbers of AMH-positive follicles per $100 \mu \mathrm{m}^{2}$ of ovarian area were estimated.

\section{Statistical analysis}

Quantitative data are represented as the means \pm SEM. Student's unpaired $t$-test was performed for single comparison between XO and XX groups. Statistical significance was assessed at a threshold P-value of 0.05 or less.

\section{Results}

\section{XO ovaries lack the first wave of folliculogenesis}

To examine the first folliculogenesis in XO mice, we conducted immunohistochemical staining of ovaries at $4 \mathrm{dpp}$ from $\mathrm{XO}$ and $\mathrm{XX}$ mice of the same litters by using anti-MVH (oocyte marker), anti-AMH (activated primary follicle marker), anti-FOXL2 (granulosa/theca cell marker), or anti-3 $\beta$-HSD (steroidogenic cell marker) antibody (Fig. 1). In XX ovaries, MVH-positive oocytes were detected throughout the whole ovarian region, including the medullary region. During the first wave of folliculogenesis, AMH-positive follicles were located only in the medullary region ("XX" in Fig. 1A, B), which is consistent with previous reports [21, 33, 34]. However, in XO ovaries, AMH-positive follicles were almost not detected throughout the entire ovarian region (numbers of $\mathrm{AMH}-$ positive follicles per $100 \mu \mathrm{m}^{2}=0.09 \pm 0.09$ in XO ovaries $[\mathrm{n}=3$ ] versus $1.08 \pm 0.14$ in XX ones [ $\mathrm{n}=7$ ], $\mathrm{P}<0.01$; also see "XO" in Fig. 1A, B). In XO ovaries, MVH-positive oocytes were observed in the cortical regions, similar to XX ovaries, but there were no MVH-positive oocytes in the medullary region (Fig. 1B). In XX ovaries, FOXL2-positive 
and $3 \beta$-HSD-positive follicles were detected in the centromedullary region (Fig. 1C). In the centromedullary region of $\mathrm{XO}$ ovaries, despite the lack of MVH-positive oocytes, FOXL2-positive and $3 \beta$-HSD-positive ovarian somatic cells were observed (Fig. 1C), suggesting presumptive pre-granulosa cells lacking oocytes. These data suggest a severe defect in the first folliculogenesis in XO ovaries, but no appreciable defects in the formation of a cortical primordial follicle pool in the surface cortical region.

\section{FOXL2/SDSI double-positive granulosa cells completely lack} oocytes in the medullary region of $\mathrm{XO}$ ovaries

Our previous study demonstrated that, during the fetal stages, SDSI-positive granulosa cells are located near the medullary region, and they contribute to the first wave of folliculogenesis in the medullary region of postnatal ovaries $[1,9]$. To examine the distribution of SDSI-positive follicles in neonatal XO ovaries, $\mathrm{XO}$ and $\mathrm{XX} \mathrm{Tg}$ were subjected to $\mathrm{HS}$ treatment $\left(43^{\circ} \mathrm{C}, 10 \mathrm{~min}\right)$ at $2 \mathrm{dpp}$ to induce ectopic SRY expression ( $\mathrm{n}=4$ for each karyotype). After the 9-h organ culture, SRY-dependent SOX9-inducible patterns were examined via anti-SOX9 immunohistochemistry.

In the 2-dpp XX Tg ovaries, SDSI-positive (i.e., SOX9-positive) granulosa cells were predominantly observed in the AMH-positive primary follicles during the first wave of folliculogenesis in the medullary region ("XX Tg" in Fig. 2), in agreement with previous data [9]. In XO ovaries, SDSI/FOXL2 double-positive granulosa cells were detected in the medullary region ("XO Tg" in Fig. 2), but they completely lacked oocytes, leading to AMH-negative/ FOXL2-positive cell clusters located within the medullary region (Figs. 1B, 1C, 2B, 2C). These results suggest that the pre-granulosa cells in the medullary region of $\mathrm{XO}$ ovaries lose most of their oocytes in the first wave of folliculogenesis.

\section{Defective phenotypes of the first folliculogenesis in XO ovaries are rescued by the second and subsequent waves of follicular growth}

In 7-dpp XO ovaries, AMH-positive primary follicles were first detected in the sub-cortical region, although their number in $\mathrm{XO}$ ovaries appeared to be smaller than in XX ovaries (Fig. 3A, B). At 14 and $21 \mathrm{dpp}, \mathrm{AMH}$-positive follicles were detected in almost the entire medullary region in $\mathrm{XO}$ ovaries, similar to what was observed in their XX littermates (Fig. 3C, D). In both XO and XX ovaries, the early and late antral follicles had the fastest-growing oocytes at 14 and $21 \mathrm{dpp}$, respectively, and by $21 \mathrm{dpp}, \mathrm{XX}$ and XO ovaries showed no apparent histological differences in the developmental stages of the fastest-growing follicles. Moreover, anti-3 $\beta$-HSD staining showed proper formation of the presumptive theca cells and ovarian interstitial gland cells around the early antral follicles in $\mathrm{XO}$ ovaries (Fig. 3E). These results suggest that subsequent waves of follicular growth are recruited and activated at $7 \mathrm{dpp}$, leading to recovery from defects in the first follicles of XO ovaries by $21 \mathrm{dpp}$.

\section{Discussion}

Our comparative analyses of $\mathrm{XX}$ and $\mathrm{XO}$ female littermates revealed that $\mathrm{XO}$ ovaries have neither $\mathrm{AMH}$-positive primordial follicles nor MVH-positive oocytes in the medullary region by $4 \mathrm{dpp}$
(Fig. 1A, B; see also Fig. 4). Because the first wave of folliculogenesis, with AMH-positive granulosa cells, initiates preferentially in the ovarian medullary region at $2-4 \mathrm{dpp}[21,33,34]$, our findings suggest defects and/or delay in the first wave of folliculogenesis in $\mathrm{XO}$ ovaries. In our previous study, SDSI-positive granulosa cells were maintained near the mesonephros throughout the fetal stages, and then contributed specifically to the initial wave of folliculogenesis soon after birth [9]. The present study, using an Hsp-Sry Tg line, showed that SDSI-positive granulosa cells lose oocytes, leading to clusters of AMH-negative and FOXL2/SDSI-double-positive cells in the medullary region by $4 \mathrm{dpp}$. These findings suggest selective loss of XO oocytes rather than a delay in the first wave of folliculogenesis in neonatal XO ovaries.

Previous extensive morphological studies showed no appreciable differences in cell death of XO oocytes before $18.5 \mathrm{dpc}$, followed by a rapid reduction in the number of oocytes throughout the ovarian parenchyma at birth [24, 27]. During female germ cell development, $\mathrm{X}$ chromosome reactivation for the erasure of genomic imprinting occurs at $10.5 \mathrm{dpc}$ [35-37], suggesting that XO germ cells express approximately half the dose of X-chromosome genes of XX wild-type germ cells at $10.5 \mathrm{dpc}$. Moreover, an asynapsed single X-chromosome occurs in some of the XO oocytes at prophase I [28, 29, 38, 39]. A recent study suggested that asynapsed chromosomes trigger oocyte elimination at diplonema through $\gamma \mathrm{H} 2 \mathrm{AFX}$-dependent transcriptional silencing [30], in which a deletion or point mutation of $H 2$ af $x$ restores oocyte numbers in XO females to wild-type XX levels. These findings suggest that such oocyte elimination may be caused mainly by a synaptic failure, rather than the half-dosage of X-chromosome genes, in XO oocytes of neonatal ovaries.

Several previous studies showed no appreciable regional differences in oocyte death in XO ovaries, in which XO oocytes appear to be lost in the surface region rather than the medullary region [27, Fig. S7 in 30]. Taken together, these findings suggest that the oocyte elimination of the first follicles appear not to be directly associated with the intrinsic differences between XO oocytes near the medullary and the cortex region of the developing ovaries. In the first folliculogenesis, the oocytes near the medullary region directly contribute to activated follicles without a resting state, in contrast to the entry of cortical follicle into the dormant state $[10,11]$. Such continuous processes of follicular formation/activation in the medullary region shortly after birth, together with the presence of SDSI-positive granulosa cells, may be associated with the complete lack of XO oocytes in the first folliculogenesis. Further studies on the distinct molecular bases of the first and subsequent waves of the follicles are required to resolve this question.

Our study also showed aberrations in the first wave of folliculogenesis in the medullary region, but the second and subsequent waves of follicular growth occurred in the subcortical region of XO ovaries by $7 \mathrm{dpp}$. Subsequently, there were no appreciable differences in the fastest-growing antral oocytes between XO and XX ovaries by $21 \mathrm{dpp}$ (Fig. 3). A previous report using a toxin receptor-mediated conditional cell knockout (TRECK) system suggested that new follicles are recruited from the subcortical region of the ovaries, with depletion of the first AMH-positive follicles in the centromedullary region [21]. As $\mathrm{Amh}^{-/-}$ovaries showed increased recruitment of primordial follicles $[40,41]$, it is likely that the loss of $\mathrm{AMH}$ in first follicles 

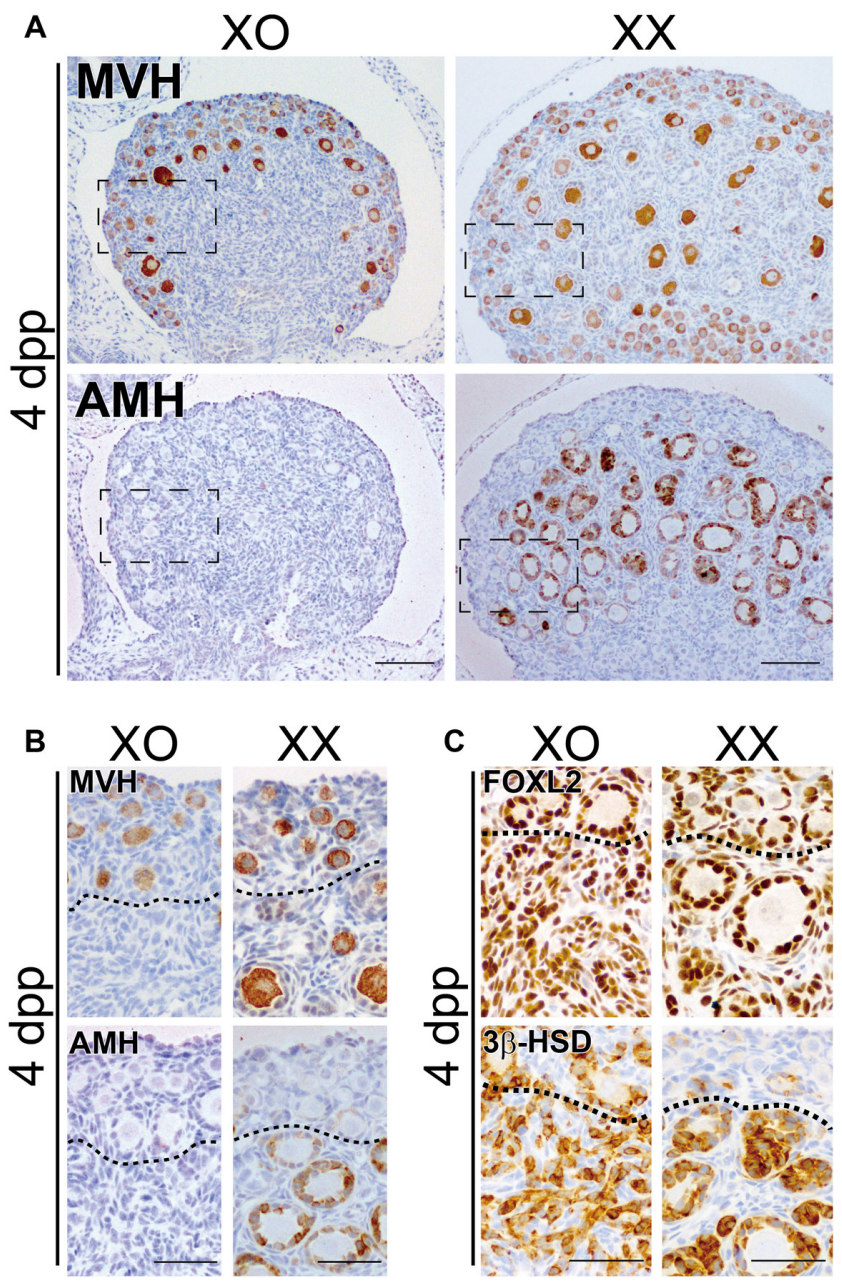

Fig. 1. XO ovaries lack the first wave of folliculogenesis. Anti-MVH (oocyte marker), AMH (activated primary follicle marker), FOXL2 (granulosa/theca cell marker) or 3 $\beta$-HSD (steroidogenic cell marker) immunostaining of XO and XX littermate ovaries at 4 days post partum (dpp). (A, B) In XO ovaries, MVH-positive oocytes are restricted to the surface cortical region, and there are no AMH-positive follicles. In XX ovaries, MVH-positive oocytes are scattered throughout the whole region, and AMHpositive follicles are enriched in the centromedullary region. (C) The centromedullary region, as well as surface cortical region, of XO ovaries is occupied by FOXL2-positive and 3 $\beta$-HSDpositive ovarian somatic cells corresponding to pre-granulosa and steroidogenic theca/interstitial gland cells. In the normal XX ovaries, FOXL2-positive and 3 $\beta$-HSD-positive follicles are mainly found in the centromedullary region. Note the increased size of the presumptive newly recruited follicles in the surface cortex region of the $\mathrm{XO}$ ovaries even at $4 \mathrm{dpp}$. Broken rectangles in (A) show the position of (B). Dotted lines in (B) and (C) indicate the border of $\mathrm{AMH}$-negative follicles in the ovarian surface region. Scale bars $=100 \mu \mathrm{m}$ in $(\mathrm{A}) ; 50 \mu \mathrm{m}$ in $(\mathrm{B}, \mathrm{C})$.

induces rapid recruitment from the subcortical region, leading to the recovery of first follicle defects in XO ovaries by $21 \mathrm{dpp}$.

In the interstitial region of $\mathrm{XO}$ ovaries, $3 \beta$-HSD-positive theca cells appeared to be properly formed at $14 \mathrm{dpp}$ (Fig. 3E). A recent study revealed that in response to oocyte-derived GDF9 signals,

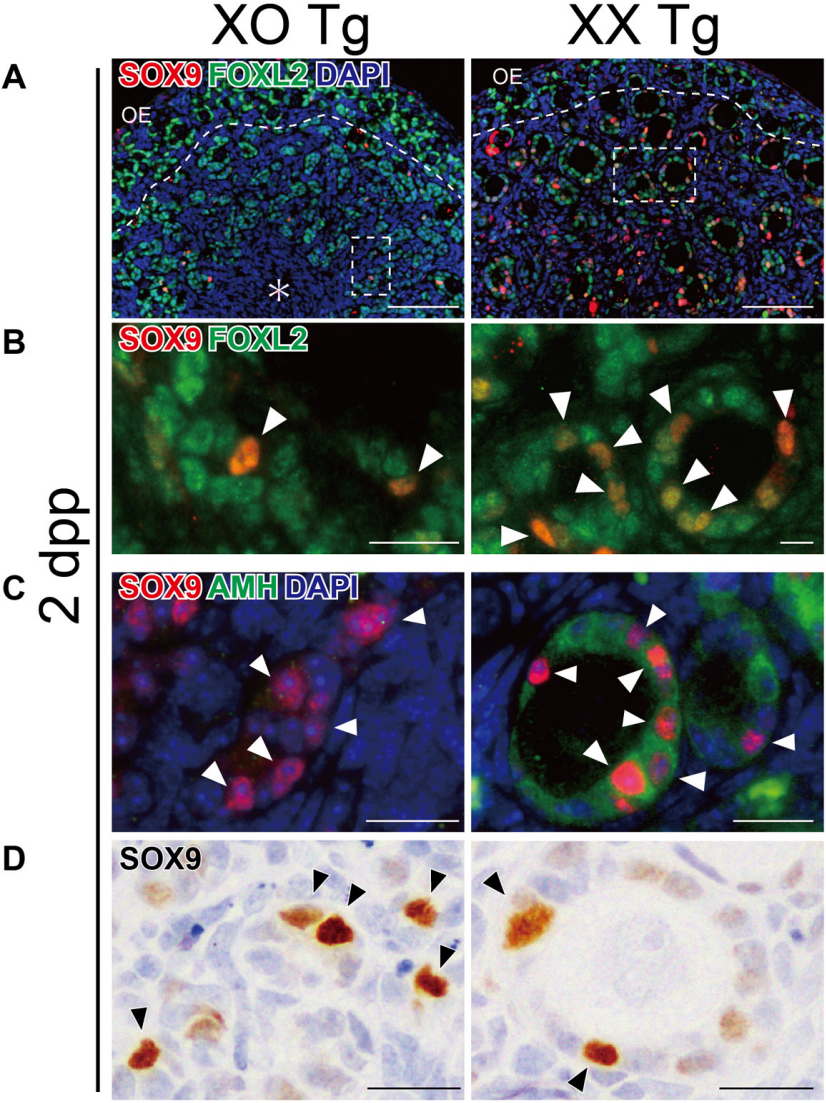

Fig. 2. Distribution patterns of SRY-dependent SOX9-inducibility (SDSI)-positive granulosa cells in the ovarian medullary region of XO and XX Hsp-Sry Tg neonates. XO and XX Hsp-Sry Tg ovaries $(2 \mathrm{dpp})$ were subjected to $\mathrm{HS}$ treatment $\left(43^{\circ} \mathrm{C}, 10 \mathrm{~min}\right)$ to induce ectopic transient SRY expression, and then cultured for $9 \mathrm{~h}$. (A, B) Anti-SOX9 (red)/FOXL2 (green) double immunostaining of $\mathrm{XO}$ and $\mathrm{XX}$ ovarian samples, showing the presence of SDSI (SOX9)-positive granulosa cells in the centromedullary region of both XO and XX ovaries. (C, D) Anti-SOX9 (red or brown)/ $\mathrm{AMH}$ (green) immunostaining of $\mathrm{XO}$ and $\mathrm{XX}$ ovarian samples, showing SDSI-positive granulosa cells in the centromedullary region of both XO and XX ovaries. SDSI (SOX9)-positive granulosa cells are enriched in the first wave of AMH-positive/ FOXL2-positive medullary follicles in XX ovaries at $2 \mathrm{dpp}$ (arrowheads in right plates). In XO ovaries of the same litter, the SDSI-positive granulosa cells show AMH-negative/FOXL2positive cell clusters in the medullary region (arrowheads in left plates), and they lack follicular structures due to a lack of oocytes. Broken rectangles in (A) show the position of (B). Dotted lines indicate the border between the cortical and medullary regions. Asterisk, mesonephric region. OE, ovarian epithelium. Scale bars $=100 \mu \mathrm{m}$ in $(\mathrm{A}) ; 20 \mu \mathrm{m}$ in $(\mathrm{B}-\mathrm{D})$.

granulosa cells express Desert and Indian Hedgehog signaling factors to induce theca cell differentiation around each growing follicle [42], suggesting proper granulosa-theca cell interactions in the early antral follicles of XO ovaries. Moreover, despite the loss of the first folliculogenesis, $3 \beta$-HSD-positive presumptive ovarian interstitial gland cells were also formed in XO ovaries (Fig. 3E), in sharp contrast to the drastic reduction in $3 \beta$-HSD-positive ovarian 


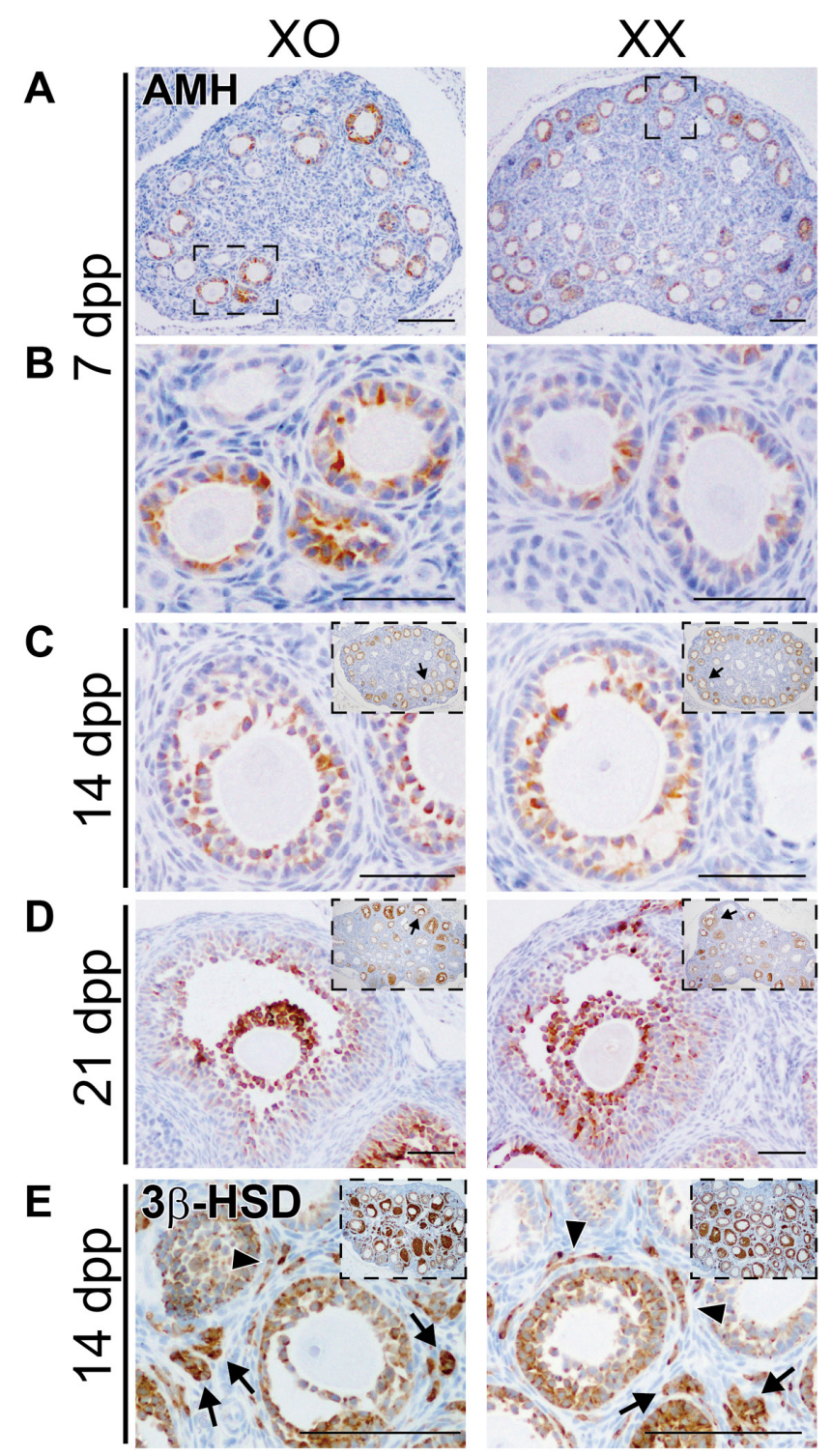

Fig. 3. Recovery of follicular growth in $\mathrm{XO}$ ovaries at 7 dpp. (A-D) Anti-AMH immunostaining of $\mathrm{XO}$ and $\mathrm{XX}$ ovaries at 7, 14, and 21 dpp. At 7 dpp, AMH-positive follicles are first detectable in the medullary side of the sub-cortical region in $\mathrm{XO}$ ovaries (A, $\mathrm{B})$. In $\mathrm{XO}$ and $\mathrm{XX}$ ovaries, the early and late antral follicles are observed at 14 and $21 \mathrm{dpp}(\mathrm{C}, \mathrm{D})$, respectively. (E) Anti-3 $\beta$-HSD immunostaining of $\mathrm{XO}$ and $\mathrm{XX}$ ovaries at $14 \mathrm{dpp}$, showing the proper formation of presumptive ovarian interstitial gland cells (arrows) and internal theca cells (arrowheads) in both ovaries by $14 \mathrm{dpp}$. In (C-E), the low-magnification images of each ovary are shown in the insets at the upper right corner, while the small arrows in the insets indicate early and late antral follicles that are magnified as the fastest-growing oocytes in each plate. Scale bars $=100 \mu \mathrm{m}$ in $(\mathrm{A}) ; 50 \mu \mathrm{m}$ in $(\mathrm{B}-\mathrm{E})$.

interstitial glands in the ablation of the AMH-positive granulosa cells of the first folliculogenesis by the TRECK system [21]. The differences between the phenotypes of these models may be explained by the contribution of the pre-granulosa cells in the first follicles to

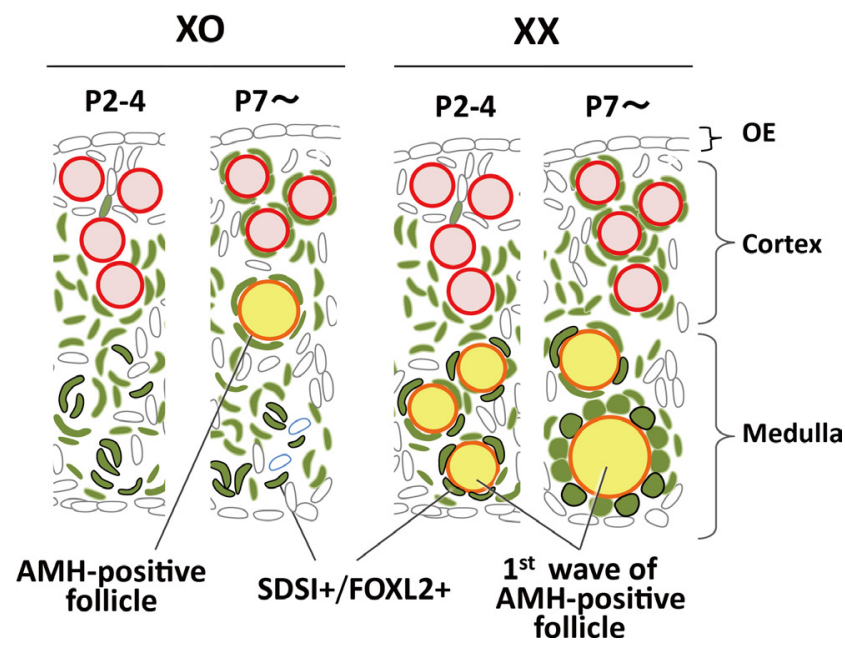

Fig. 4. Schematic representation of the defective first folliculogenesis in XO ovaries. In XX ovaries (right), the SDSI/FOXL2 doublepositive cells (green cells with solid outline) contribute to the first wave of AMH-positive follicle formation in the medullary region (yellow). In the cortical region, a primordial follicle pool (red) is formed by $7 \mathrm{dpp}$. In XO ovaries (left), the oocytes are eliminated near the SDSI/FOXL2 double-positive pre-granulosa cells, leading to a loss of the first follicles in the medullary region by $4 \mathrm{dpp}$. In the subcortical region, $\mathrm{AMH}$-positive follicles are recruited at $7 \mathrm{dpp}$, which results in recovery from the defects in follicular growth of XO ovaries by $21 \mathrm{dpp}$. The green cells show FOXL2-positive somatic cells, while red and yellow cells show oocytes. OE, ovarian epithelium; SDSI, SRY-dependent SOX9 inducibility. Figure adapted from Suzuki et al. (2015) [1].

the proper formation of ovarian interstitial glands in the interstitial region of the $\mathrm{XO}$ ovaries, in contrast to the ablation of almost all of the AMH-positive granulosa cells in the first follicles by the TRECK system.

In conclusion, the present data provide direct evidence of severe defects in the first folliculogenesis in XO ovaries, while, in sharp contrast, the cortical follicle pool still forms properly, leading to an escape from female sterility through subsequent waves of follicular growth. Such distinct susceptibilities to X-monosomy effects on the first vs. subsequent folliculogenesis highlight the importance of studying the molecular mechanisms of both the first and subsequent waves of follicular formation/activation in mammalian postnatal ovaries.

\section{Acknowledgments}

The authors wish to thank Drs Hinako M Takase, Hiroyuki Sumitomo, Hiroki Higashiyama, Yoshiko Kuroda, Yoshikazu Hirate for their helpful supports and advice, and Ms Itsuko Yagihashi and Yuki Uchiyama for their secretarial and technical supports. This work was supported by Grants-in-Aid for Scientific Research (KAKENHI) on Priority Areas and Innovative Areas (YK). KM is DC1 JSPS Research Fellows. 


\section{References}

1. Suzuki H, Kanai-Azuma M, Kanai Y. From sex determination to initial folliculogenesis in mammalian ovaries: morphogenetic waves along the anteroposterior and dorsoventral axes. Sex Dev 2015; 9: 190-204. [Medline] [CrossRef]

2. Rimon-Dahari N, Yerushalmi-Heinemann L, Alyagor L, Dekel N. Ovarian folliculogenesis. Results Probl Cell Differ 2016; 58: 167-190. [Medline] [CrossRef]

3. Uhlenhaut NH, Jakob S, Anlag K, Eisenberger T, Sekido R, Kress J, Treier AC, Klugmann C, Klasen C, Holter NI, Riethmacher D, Schütz G, Cooney AJ, LovellBadge R, Treier M. Somatic sex reprogramming of adult ovaries to testes by FOXL2 ablation. Cell 2009; 139: 1130-1142. [Medline] [CrossRef]

4. Boulanger L, Pannetier M, Gall L, Allais-Bonnet A, Elzaiat M, Le Bourhis D, Daniel N, Richard C, Cotinot C, Ghyselinck NB, Pailhoux E. FOXL2 is a female sexdetermining gene in the goat. Curr Biol 2014; 24: 404-408. [Medline] [CrossRef]

5. Bertho S, Pasquier J, Pan Q, Le Trionnaire G, Bobe J, Postlethwait JH, Pailhoux E, Schartl M, Herpin A, Guiguen Y. Foxl2 and its relatives are evolutionary conserved players in gonadal sex differentiation. Sex Dev 2016; 10: 111-129. [Medline] [CrossRef]

6. Pannetier M, Chassot AA, Chaboissier MC, Pailhoux E. Involvement of FOXL2 and RSPO1 in ovarian determination, development, and maintenance in mammals. Sex Dev 2016; 10: 167-184. [Medline] [CrossRef]

7. Harikae K, Miura K, Kanai Y. Early gonadogenesis in mammals: significance of long and narrow gonadal structure. Dev Dyn 2013; 242: 330-338. [Medline] [CrossRef]

8. Hiramatsu R, Matoba S, Kanai-Azuma M, Tsunekawa N, Katoh-Fukui Y, Kurohmaru M, Morohashi K, Wilhelm D, Koopman P, Kanai Y. A critical time window of Sry action in gonadal sex determination in mice. Development 2009; 136: 129-138. [Medline] [CrossRef]

9. Harikae K, Miura K, Shinomura M, Matoba S, Hiramatsu R, Tsunekawa N, KanaiAzuma M, Kurohmaru M, Morohashi K, Kanai Y. Heterogeneity in sexual bipotentiality and plasticity of granulosa cells in developing mouse ovaries. J Cell Sci 2013b; 126: 2834-2844. [Medline] [CrossRef]

10. Mork L, Maatouk DM, McMahon JA, Guo JJ, Zhang P, McMahon AP, Capel B. Temporal differences in granulosa cell specification in the ovary reflect distinct follicle fates in mice. Biol Reprod 2012; 86: 37. [Medline] [CrossRef]

11. Zheng W, Zhang H, Gorre N, Risal S, Shen Y, Liu K. Two classes of ovarian primordial follicles exhibit distinct developmental dynamics and physiological functions. Hum Mol Genet 2014; 23: 920-928. [Medline] [CrossRef]

12. Hirshfield AN. Heterogeneity of cell populations that contribute to the formation of primordial follicles in rats. Biol Reprod 1992; 47: 466-472. [Medline] [CrossRef]

13. Hirshfield AN, DeSanti AM. Patterns of ovarian cell proliferation in rats during the embryonic period and the first three weeks postpartum. Biol Reprod 1995; 53: 1208-1221. [Medline] [CrossRef]

14. Zheng W, Zhang H, Liu K. The two classes of primordial follicles in the mouse ovary: their development, physiological functions and implications for future research. Mol Hum Reprod 2014; 20: 286-292. [Medline] [CrossRef]

15. Couse JF, Hewitt SC, Bunch DO, Sar M, Walker VR, Davis BJ, Korach KS. Postnatal sex reversal of the ovaries in mice lacking estrogen receptors alpha and beta. Science 1999; 286: 2328-2331. [Medline] [CrossRef]

16. Dupont S, Dennefeld C, Krust A, Chambon P, Mark M. Expression of Sox 9 in granulosa cells lacking the estrogen receptors, ERalpha and ERbeta. Dev Dyn 2003; 226: 103-106. [Medline] [CrossRef]

17. Schmidt D, Ovitt CE, Anlag K, Fehsenfeld S, Gredsted L, Treier AC, Treier M. The murine winged-helix transcription factor Foxl2 is required for granulosa cell differentiation and ovary maintenance. Development 2004; 131: 933-942. [Medline] [CrossRef]

18. Uda M, Ottolenghi C, Crisponi L, Garcia JE, Deiana M, Kimber W, Forabosco A, Cao A, Schlessinger D, Pilia G. Foxl2 disruption causes mouse ovarian failure by pervasive blockage of follicle development. Hum Mol Genet 2004; 13: 1171-1181. [Medline] [CrossRef]

19. Ottolenghi C, Pelosi E, Tran J, Colombino M, Douglass E, Nedorezov T, Cao A, Forabosco A, Schlessinger D. Loss of Wnt4 and Foxl2 leads to female-to-male sex reversal extending to germ cells. Hum Mol Genet 2007; 16: 2795-2804. [Medline] [CrossRef]

20. Takeo T, Nakagata N. Superovulation using the combined administration of inhibin antiserum and equine chorionic gonadotropin increases the number of ovulated oocytes in C57BL/6 female mice. PLoS ONE 2015; 10: e0128330. [Medline] [CrossRef]

21. Shinomura M, Kishi K, Tomita A, Kawasumi M, Kanezashi H, Kuroda Y,
Tsunekawa N, Ozawa A, Aiyama Y, Yoneda A, Suzuki H, Saito M, Picard JY, Kohno K, Kurohmaru M, Kanai-Azuma M, Kanai Y. A novel Amh-Treck transgenic mouse line allows toxin-dependent loss of supporting cells in gonads. Reproduction 2014; 148 H1-H9. [Medline] [CrossRef]

22. Probst FJ, Cooper ML, Cheung SW, Justice MJ. Genotype, phenotype, and karyotype correlation in the XO mouse model of Turner syndrome. J Hered 2008; 99: 512-517. [Medline] [CrossRef]

23. Sybert VP, McCauley E. Turners syndrome. $N$ Engl J Med 2004; 351: 1227-1238. [Medline] [CrossRef]

24. Lyon MF, Hawker SG. Reproductive lifespan in irradiated and unirradiated chromosomally XO mice. Genet Res 1973; 21: 185-194. [Medline] [CrossRef]

25. Yang $\mathbf{F}$, Babak $\mathbf{T}$, Shendure $\mathbf{J}$, Disteche $\mathbf{C M}$. Global survey of escape from X inactivation by RNA-sequencing in mouse. Genome Res 2010; 20: 614-622. [Medline] [CrossRef]

26. Burgoyne PS, Baker TG. Oocyte depletion in XO mice and their XX sibs from 12 to 200 days post partum. J Reprod Fertil 1981; 61: 207-212. [Medline] [CrossRef]

27. Burgoyne PS, Baker TG. Perinatal oocyte loss in XO mice and its implications for the aetiology of gonadal dysgenesis in XO women. J Reprod Fertil 1985; 75: 633-645. [Medline] [CrossRef]

28. Turner JM, Mahadevaiah SK, Fernandez-Capetillo O, Nussenzweig A, Xu X, Deng CX, Burgoyne PS. Silencing of unsynapsed meiotic chromosomes in the mouse. Nat Genet 2005; 37: 41-47. [Medline]

29. Alton M, Lau MP, Villemure M, Taketo T. The behavior of the X-and Y-chromosomes in the oocyte during meiotic prophase in the B6.Y(TIR)sex-reversed mouse ovary. Reproduction 2008; 135: 241-252. [Medline] [CrossRef]

30. Cloutier JM, Mahadevaiah SK, ElInati E, Nussenzweig A, Tóth A, Turner JM. Histone H2AFX Links Meiotic Chromosome Asynapsis to Prophase I Oocyte Loss in Mammals. PLoS Genet 2015; 11: e1005462. [Medline] [CrossRef]

31. Raznahan A, Probst F, Palmert MR, Giedd JN, Lerch JP. High resolution whole brain imaging of anatomical variation in XO, XX, and XY mice. Neuroimage 2013; 83. 962-968. [Medline] [CrossRef]

32. Matoba S, Hiramatsu R, Kanai-Azuma M, Tsunekawa N, Harikae K, Kawakami H, Kurohmaru M, Kanai Y. Establishment of testis-specific SOX9 activation requires highglucose metabolism in mouse sex differentiation. Dev Biol 2008; 324: 76-87. [Medline] [CrossRef]

33. Münsterberg A, Lovell-Badge R. Expression of the mouse anti-müllerian hormone gene suggests a role in both male and female sexual differentiation. Development 1991; 113 613-624. [Medline]

34. Lécureuil C, Fontaine I, Crepieux P, Guillou F. Sertoli and granulosa cell-specific Cre recombinase activity in transgenic mice. Genesis 2002; 33: 114-118. [Medline] [CrossRef]

35. Monk M, McLaren A. X-chromosome activity in foetal germ cells of the mouse. $J$ Embryol Exp Morphol 1981; 63: 75-84. [Medline]

36. Sugimoto M, Abe K. X chromosome reactivation initiates in nascent primordial germ cells in mice. PLoS Genet 2007; 3: e116. [Medline] [CrossRef]

37. Chuva de Sousa Lopes SM, Hayashi K, Shovlin TC, Mifsud W, Surani MA, McLare A. X chromosome activity in mouse XX primordial germ cells. PLoS Genet 2008; 4: e30 [Medline] [CrossRef]

38. Speed RM. Oocyte development in XO foetuses of man and mouse: the possible role of heterologous X-chromosome pairing in germ cell survival. Chromosoma 1986; 94 115-124. [Medline] [CrossRef]

39. Mahadevaiah SK, Lovell-Badge R, Burgoyne PS. Tdy-negative XY, XXY and XYY female mice: breeding data and synaptonemal complex analysis. J Reprod Fertil 1993; 97 151-160. [Medline] [CrossRef]

40. Durlinger AL, Kramer P, Karels B, de Jong FH, Uilenbroek JT, Grootegoed JA, Themmen AP. Control of primordial follicle recruitment by anti-Müllerian hormone in the mouse ovary. Endocrinology 1999; 140: 5789-5796. [Medline]

41. Visser JA, Durlinger AL, Peters IJ, van den Heuvel ER, Rose UM, Kramer P, de Jong FH, Themmen AP. Increased oocyte degeneration and follicular atresia during the estrous cycle in anti-Müllerian hormone null mice. Endocrinology 2007; 148: 2301-2308. [Medline] [CrossRef]

42. Liu C, Peng J, Matzuk MM, Yao HH. Lineage specification of ovarian theca cells requires multicellular interactions via oocyte and granulosa cells. Nat Commun 2015; 6 : 6934. [Medline] [CrossRef] 